\title{
The Impact of Company Accounts on Accounting Information Generation for Decision Making of Small and Medium Enterprises in Nigeria
}

\author{
Olaoye, Ayoola Azeez \\ Bsc (Ed), (Acct), Msc (Acct) \& ACA \\ Doctoral Student, School of Post Graduate Studies, Faculty of Management Sciences, Department of \\ Accounting, Ekiti State University, Ado-Ekiti, Nigeria \\ Dr. C. O. Olaoye \\ Senior Lecturer, Accounting Department, Ekiti State University, Ado-Ekiti, Nigeria
}

\begin{abstract}
Small and medium scale enterprises are gaining widespread acceptance as viable drivers of economic growth. However, several of these enterprises demise without fulfilling expectations due to poor management arising from weak accounting structure and information, and the studies of the impact of company accounts on accounting information generation are very few and not fully explored in the literature especially in Nigeria. This study therefore, examines the impact of company account on the generation of accounting information for decision making of small and medium enterprises (SMEs) in Nigeria. A survey research design approach was adopted through the administration of questionnaire to obtain primary data from respondents. The sample size of 151 respon-dents was drawn from 15 selected SMEs in Osun State. A stratified sampling technique was used to draw the sample. The data collected was analyzed using Linear Multiple Regression mode. From the results obtained, there is strong relationship between the company accounts and accounting information as indicated by the correlation coefficient of $0.955,0.958,0.962$ and the $\mathrm{p}$-value is less than $1 \%$ significant level $(0.00<0.01)$, therefore null hypotheses are rejected. That means company accounts play significant role in generating accounting information for decision making of business organizations in Nigeria. This study finds that some SMEs operators in Osun State hired unskilled accounting personnel which make their accounting information unreliable and inadequate for effective decision making and very difficult to measure the performances of their business. This study recommends that government should promulgate new additional company law that will extend mandatory annual statutory preparation, disclosure and publication of annual accounts and reports of limited liability companies to other uncovered small and medium enterprises in Nigeria.
\end{abstract}

Keywords: Accounting information, Company accounts, Small and Medium Enterprises.

DOI: $10.7176 /$ RJFA/11-11-04

Publication date:June 30th 2020

\section{Introduction}

Keeping of proper records and writing of financial statements have enormous benefits for firms (Rathnasiri, 2014). The importance of adequate company accounts preparation is to generate information for the growth and decision making of SMEs (Onaolapo \& Adegbite, 2014). Company accounts serve as a means of monitoring performance and measuring the accuracy of income and expenditure (Ismaila, 2011). It is essential to point out that the purpose of company financial accounting is not only to report the value of the company, but also to provide enough information for others to assess the value of a company for their decision making (Abor \& Biekpe, 2006). A business is the organized effort of persons utilizing resources within an organizational context to produce and distribute goods and services for the purpose of profit making (Osunwole, 2013). There are various forms of business organizations such as sole proprietorship, partnership, and limited liability company (Nigerian Accounting Standards Board (NASB), 2010). However, in respect of the form, some of these businesses still fall under the category of SMEs in Nigeria.

Ademola, Samuel and Ifedolapo (2012) affirm that keeping of proper books of accounts enables SMEs to have accurate and reliable information that will help in making economic decisions. Ademola et al (2012) further explain that the SMEs play a very significant role in international trade as many of them are involved in exportation of raw materials. African countries for instance, Nigeria is the most populous country in Africa and a major exporter of agricultural produce. The importance of keeping company accounts is to promote the growth of SMEs (Akande, 2011). In Nigeria, the limited liability companies are required to keep the track records of their activities taking place from time to time. The Company and Allied Matter Act (CAMA, 1990) as amended stipulated that all the registered companies under it are to publish their audited annual accounts and reports in the at least two national news papers annually in compliance with the Statement of Accounting Standards (SAS) issued by the Nigeria Accounting Standards Board (NASB) now called the Financial Reporting Council of Nigeria (FRCN) 
prior to International Financial Reporting Standards (IFRSs) adoption (Osunwole, 2013).

Apart from the above, lack of accurate and proper accounting records is believed to be one of the causes of closure of many SMEs and it makes it an important aspect for business success. Baldwin, Bian, Dupuy and Gellatly. (2000) observe that many firms fail at an early stage; with the surviving ones failing to grow sustainably. This is attributed to lack of accounting information which is an important tool in efficient management and decision making (Baldwin et al, 2000). Many business owners undermine the importance of company accounts preparation for generating information despite its pivotal role in decision making and efficient management of business (Jefferson, 2012). Many small and medium enterprises operators fail to recruit qualified accounting experts who have all it take to prepare accurate, reliable and acceptable accounts for their companies that will generate accounting information for decision making (Bouri, Breji, Diop, Kempner, Klinger \& Stevenson, 2011). Accounting information is very critical for the survival and growth of every business unit (Okoh et al, 2012). The reviewed previous studies indicate that business owners were unable to operate their businesses efficiently and make economic decisions in their daily operations due to inadequate accounting information. Aside that, studies of the impact of company accounts on accounting information generation are very few and not absolutely explored in the literature especially in Nigeria. It is against the bedrock of these gaps that this study seeks to examine the impact of company accounts preparation on the generation of accounting information for decision making of SMEs in Nigeria. Findings from this study will help the SMEs owners to appreciate the importance of company accounts preparation on the generation of accounting information for decision making and survival of their businesses in a competitive market.

\section{Conceptual Review}

\subsection{Company Accounts}

Company accounts are the final accounts of limited liability companies containing the income statement and the statements of financial position as well as other statements and information about an entity in a particular accounting period (Onaolapo, Opoola \& Olatunji, 2011). Company accounts serve as a means of monitoring performance and measuring the accuracy of income and expenditure (Ismaila, 2011). Company accounting is an important management information tool for every business because they provide an accurate reflection of financial performance of the business (Onaolapo et al, 2011). It is essential to point out that the purpose of company financial accounting is not only to report the value of the company, but also to provide enough information for others to assess the value of a company for their decision making (Abor et al, 2006). Accounting for a limited company is concerned with record-keeping of financial transactions for an entity. Company accounting is important because it enables businesses organizations to understand their financial position at any given time which enhances the development of strategies to reposition business for further expansion and growth (Abdul-Rahman \& Adejare, 2014).

Accounting records provide a basis for complete and accurate income tax computation, a basis for sound planning for the future and basis for discussion with partners, potential investors and lenders. All these are important aspects which enhance performance of the SMEs. Mutambanengwe (2012) says that keeping records is crucial for the successful performance of an SME. A comprehensive record keeping system makes it possible for entrepreneurs to develop accurate and timely financial reports that show the progress and current condition of the business. An accurate record of the business's financial performance is a vehicle for monitoring performance in specific areas (Smallbone, Welter, Voytovich \& Egorov, 2010). The variables used in this study to examine the impact of company accounts on the generation of accounting information for decision making of a business include: The income statement (IS), the statement of financial position (SFP) and the cash flow statement (CFS).

\subsubsection{Income Statement}

The income statement formerly known as profit and loss account and which other scholars termed as the statement of income, statement of earnings and statement of operations is the summary of income and expenses, gains and losses of a business organization which determine the gross and net profit/loss for a specific period.

\subsubsection{Statement of Financial Position}

Statement of financial position shows the present state of affairs of a business and it contains assets and liabilities of an entity (Olaoye, 2012).

\subsubsection{Cash Flow Statement}

The cash flow Statement shows cash inflow and outflow in the organization. The statement analyzes the cash flow benefits for short-term planning with a view to generating enough cash to settle indebtedness maturing in the near future, to pay interest on borrowing and other expenses and to pay dividends to shareholders. Okafor (2012) stood firm that the management of business organizations can use cash flow statement for dividend posting, cash generated by operations, investing and financing policy.

\subsubsection{Accounting Information}

Business depends on correct accounting information to make good decisions about the firm (Okoh et al, 2012). Therefore if proper records are kept they will facilitate efficient, proper timely decision making and enhance 
performance in small scale industry (Halabi \& Lussier, 2014). With the financial report generated from a company accounting information system, performance during one period of time (month, quarter or year) with another period can be compared. Towards a new model of success and performance in business organizations, Simpson, Padmore and Newman (2012) affirm that accounting information users are on the increase. Accounting information can be assembled and evaluated in a way that can help the management of firms to make informed decisions concerning the operation, survival and growth of the firm. Accounting information system is a powerful tool which collects information about different transactions to help management keep record of what happens or affects the organization (Okoh et al, 2012;). Accounting information system can be manual or automated (Oladejo, 2008).

\subsection{Theoretical Review}

This study theoretical review was anchored on the decision theory pioneered by Herber Simon in 1952. Decision theory is concerned with identification of the best alternative option to be used in making financial decisions (Akande, 2011). Akande. (2011) observed that the essence of this theory is that decision-making is not a spontaneous process but a cognizance assessment of the probable choices that optimizes the desired goal. Decision theory of accounting is pertinent in comprehending the impact of company accounts on the generation of accounting information for decision making of business organization in Nigeria. Accounting functions are entwined with managerial analysis because, as an information system it offers momentous meaningful information about the firm both for internal management use and external financial reporting (Akande, 2011). Therefore the decision theory is relevant to this study in explaining the relations of the study's explanatory variables of income statement and statement of financial position that will help the owners of SMEs in their routine decisions making processes.

\subsection{Empirical Review}

The empirical review of this study is based on the similar works done by other researchers on the subject matter under review conducted in Nigeria and the rest of the world and these include a study conducted by AbdulRahamon et al (2014) on the analysis of the impact of accounting records-Keeping on the performance of the small scale enterprises. The study adopted a survey research design and used correlation to analyze the data collected. The study found that proprietary company failures can be attributed to inadequate or no accounting records. The study concluded that the effect of accounting records on the success or failure of businesses of the proprietary companies are minimal and recommended for further research on causes of business failures.

A survey conducted by Williams (2010) to investigate a longitudinal analysis of the characteristics and performance of small business in Australia. The study used expo-fato research design approach. Data was analyzed using regression model. The study found out that $57 \%$ of the respondents used the double entry systems. This finding is in contradicted to Peacock's (2008) findings of types of records kept by enterprises that failed, where only $2.1 \%$ of respondents were found to be using double entry systems. The study recommended for further research on the effects of book keeping on the growth of SMEs. In a study conducted by Sauser (2005) on starting your own business and prepare for success. The study adopted a descriptive research design and used content analysis. The outcome of the study embraced the ideal of maintaining adequate company accounts that will generate financial information for the owners and management of business organization at initial stage of a business.

A study carried out by McLarty, Pichanic and Sarapova (2012) on the factors influencing the performance of small and medium enterprises. The study used a descriptive research design. Findings from the study revealed that lack of proper company accounting has negative effects on the ability of managements and owners of SMEs to make effective decision on the performance and growths of their enterprises. Finally, a review of study conducted by Abor et al, (2006), on small business financing initiatives in Ghana, problems and perspectives in management. The study employed content analysis and descriptive research design. The result of the study observed that businesses that have the interested in determining their profitability and to ascertain the profit, they should embrace suitable accounting bases, concepts, principles and standards to ensure the consistency of its measurement. Accounting records can help improve the performance of a business and as Abdul-Rahamon et at (2014) noted, a strong positive relationship between accounting records keeping and growth of SMEs' financial records.

\section{Research Methodology}

This study adopted a survey research design and employed both primary and secondary data. The population of this study is made up of the 67 selected business organizations especially the limited liability companies in Osun State, Nigeria. The sample size of 200 respondents was drawn randomly. The questionnaire was used and administered to the accounting staffs, available owners and members of management of the selected firms. The secondary data sources include journals, books, e-books. Of the 200 administered copies of the questionnaire, 157 
were returned but only 150 copies were completed and considered valid representing $83 \%$ of the sample size for the analysis. The validity of the questionnaires was done through the use of expert in the field of Accountancy and a Cronbach's Alpha test reliability yielded a stability Co-efficient of 99.2\% was considered well enough for the reliability of this study. The instrument consist of a 4-term liker scale response options of strongly Agree (SA - 4); Agree (A - 3); Strongly Disagree (D-2); Disagree ( $S D-1)$. The official position of the respondents was considered when the questionnaires were being administered. The opinions of respondents were sought by using the Multiple Regression technique to analyze the data with the help of SPSS version 20 to confirm the hypotheses of the study tested at $1 \%$ level of significance.

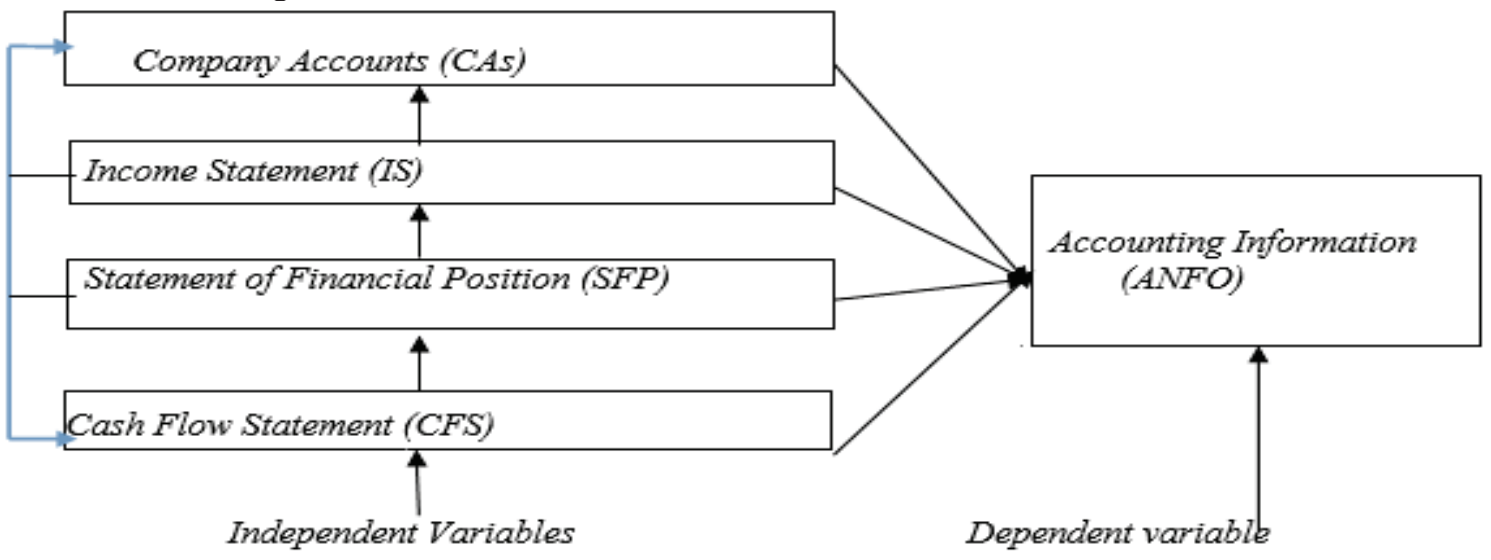

Figure 3.1: Conceptual Model of the Study

Source: Author's Compilation (2020)

The table 1.1 above shows the conceptual model was developed to show the role of the independent variable (CAs) on the dependent variable (ANFO). The independent of company accounts is made up of three explanatory independent variables of IS, SFP and CFS Thus, the model gives the snapshot of the importance and role of company accounts in generating the accounting information for decision making of business organizations in Nigeria.

\subsection{Model Specification and Identification of Variables}

This study employed regression model of forensic accounting services and fraudulence practices adopted by Anuolam et al (2016) as follow:

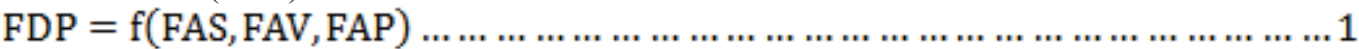

$$
\begin{aligned}
& F D P=f\left(\alpha_{0}+\beta_{1} \text { FAS }+\beta_{2}\right. \text { FAV }
\end{aligned}
$$

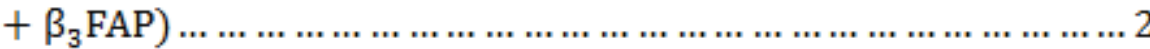

The dependent variable of fraudulent practices (FDP) was used as a function of the three components of independent variables of FAS (Forensic Accounting Services), FAV (Forensic Accounting Validation) and FAP (Forensic Accounting Practices). This study therefore replaced the variables used by Anuolam et al (2016) with a dependable variable of accounting information (ANFO) as a function of the three explanatory variables of income statement (IS), statement of financial position (SFP) and the cash flow statement (CFS) to form the specific objectives and research hypotheses in order to capture the impact of the company accounts on the generation of accounting information for decision making of SMEs in Nigeria. The model is as follow:

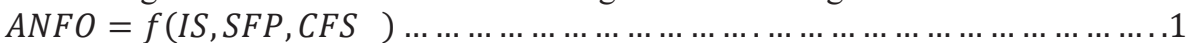

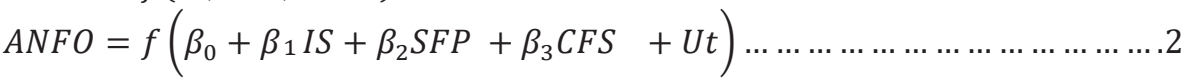

$$
\begin{aligned}
& \text { where: } \beta_{0} \text { is constants, } U_{\mathrm{t}} \text { stochastic error term and } \beta_{1}, \beta_{2},, \beta_{3} \text { are parameters/coefficients. }
\end{aligned}
$$

\subsection{A priori Expectation}

There are expected to be the impact of company accounts on accounting information generation for decision making of some selected SMEs in Nigeria as described symbolically below:

$\beta_{1}, \beta_{2}, \beta_{3},>0$ 


\section{Data Presentation and Analysis}

Table 4.1 Reliability Statistical Test

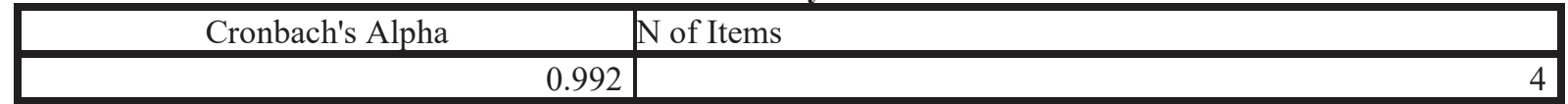

Source: Author's Computation (2020)

Table 2 above showed Cronbach's Alpha coefficient of 0.992 which above the value of Cronbach's Alpha coefficient recommended by George and Mallery (2003) that the statistical reliability value is expected be 0.70 or above. This indicates that the questionnaire is reliable.

Table 4.2 Descriptive Statistics of the Study's Variables

\begin{tabular}{|c|c|c|c|}
\hline & Mean & Std. Deviation & $\mathrm{N}$ \\
\hline ANFO & 3.3311 & 0.90717 & 151 \\
\hline IS & 3.2980 & 0.97840 & 151 \\
\hline SFP & 3.2517 & 1.00809 & 151 \\
\hline CFS & 3.2980 & 0.97840 & 151 \\
\hline
\end{tabular}

Source: Author's Computation (2020)

Note: $\mathrm{ANFO}=$ Accounting information, $\mathrm{IS}=$ Income statement, SFP $=$ Statement of financial position and CFS $=$ Cash flow statement. In table 4.2, the mean values of 3.2980, 3.2517 and 3.2980 of the explanatory independent variables of IS, SFP and CFS respectively are high enough and their corresponding standard deviations of 0.978 , 1.008 and 0.978 are normally distributed. This indicates that the respondents agreed and strongly agreed that company accounts play significant roles in generating accounting information for decision making of SMEs in Nigeria.

Table 4.3 Regression Correlation of the Study's Variables

\begin{tabular}{|c|c|c|c|c|c|}
\hline & & ANFO & IS & SFP & CFS \\
\hline \multirow{5}{*}{ Pearson Correlation } & ANFO & 1.000 & 0.955 & 0.958 & 0.962 \\
\hline & IS & 0.955 & 1.000 & 0.978 & 0.986 \\
\hline & SFP & 0.958 & 0.978 & 1.000 & 0.978 \\
\hline & CFS & 0.962 & 0.986 & 0.978 & 1.000 \\
\hline & ANFO & & 0.000 & 0.000 & 0.000 \\
\hline \multirow{5}{*}{ Sig. (1-tailed) } & IS & 0.000 & & 0.000 & 0.000 \\
\hline & SFP & 0.000 & 0.000 & & 0.000 \\
\hline & CFS & 0.000 & 0.000 & 0.000 & \\
\hline & ANFO & 151 & 151 & 151 & 151 \\
\hline & IS & 151 & 151 & 151 & 151 \\
\hline \multirow{2}{*}{$\mathrm{N}$} & SFP & 151 & 151 & 151 & 151 \\
\hline & CFS & 151 & 151 & 151 & 151 \\
\hline
\end{tabular}

Source: Author's Computation (2020)

Note: $\mathrm{ANFO}=$ Accounting information, $\mathrm{IS}=$ Income statement, SFP $=$ Statement of financial position and CFS $=$ Cash flow statement. The result of correlation analysis in table 4.3 above shows a strong relationship between Accounting information and the company accounts given the relationship results of $(0.955,0.958,0962)$ for the explanatory variables of income statement, statement of financial position and the cash flow statement respectively where the p-value of 0.000 is less than the 0.01 level of significant, i.e. $(0.000<0.01)$. Thus, null hypotheses should be rejected. This means there is strong significant and positive association between the independent variables and the dependent variable.

Table 4.4 Regression Model Summary

\begin{tabular}{|l|r|r|r|r|}
\hline Model & \multicolumn{1}{|c|}{ R } & R Square & \multicolumn{1}{c|}{ Adjusted R Square } & Std. Error of the Estimate \\
\hline 1 & $0.966^{\mathrm{a}}$ & 0.932 & 0.931 & 0.23811 \\
\hline
\end{tabular}

Source: Author's Computation (2020)

Predictors: (Constant), Cash Flow Statement, Statement of Financial Position, Income Statement. From table 4.4 above, the model summary results indicate that the coefficient of relationship (R) (0.966) for the hypotheses at a significant level of 0.01 shows a strong relationship. Then the coefficient of determination $\left(\mathrm{R}^{2}\right)(0.932)$ also shows a strong positive correlation of the studies variables, which indicates that about $93.2 \%$ of variation in the dependent variable (CFCs) is explained by the independent variables (IS, SFP and CFS) or the ability of the regression line to predict dependent variable (ANFO) is about $93.2 \%$. The other $6.8 \%$ is explained by other factors outside the model and the error term. Thus, null hypotheses are rejected and alternative hypotheses accepted. That is, company accounts play significant roles in generating accounting information for decision making of SMEs in Nigeria 
Table 4.5 Regression Coefficients

\begin{tabular}{|c|c|c|c|c|c|c|}
\hline \multicolumn{2}{|c|}{ Model } & \multicolumn{2}{|c|}{ Un-standardized Coefficients } & \multirow{2}{*}{\begin{tabular}{|c|}
$\begin{array}{l}\text { Standardized } \\
\text { Coefficients }\end{array}$ \\
Beta \\
\end{tabular}} & \multirow[t]{2}{*}{$\mathrm{T}$} & \multirow[t]{2}{*}{ Sig. } \\
\hline & & $\mathrm{B}$ & Std. Error & & & \\
\hline \multirow{4}{*}{1} & (Constant) & 0.413 & 0.069 & & 5.960 & 0.000 \\
\hline & IS & 0.022 & 0.130 & 0.024 & 0.170 & 0.000 \\
\hline & SFP & 0.346 & 0.100 & 0.384 & 3.449 & 0.000 \\
\hline & CFS & 0.522 & 0.130 & 0.563 & 4.021 & 0.000 \\
\hline
\end{tabular}

Source: Author's Computation (2020)

Dependent Variable: Accounting Information

Note: $\mathrm{ANFO}=$ Accounting information, $\mathrm{IS}=$ Income statement, $\mathrm{SFP}=$ Statement of financial position and CFS $=$ Cash flow statement

The result from table 3 above revealed that predictor variables of income statement (IS) where $t=0.170$, and $\mathrm{p}=0.00<0.01$ and statement of financial position (SFP) where $\mathrm{t}=3.449$, and $\mathrm{p}=0.00<0.01$ then, cash flow statement $(\mathrm{CFS})$ where $t=4.021$, and $\mathrm{p}=0.00<0.01$ have significant positive relationship with dependent variable (ANFO). Then, based on the linear equation of the predictor variables coefficients, that is: $A N F O=0.413+0.022 b_{1}$ $+0.346 b_{2}+0.522 b_{3}+U t$, the equation depicted that the role of generating accounting information for decision making of SMEs in Nigeria is determined by $1 \%$ increase in each of the company accounts explanatory variables of IS, SFP and CFS.

\section{Discussion of Results}

The coefficient of relationship (R) of 0.966 for the hypotheses at a significant level of 0.01 showed a strong relationship and the coefficient of determination $\left(R^{2}\right)(0.932)$ shows a moderate positive correlation of the studies variables, which indicates the ability of the regression line to predict dependent variable (ANFO) is about $93.2 \%$. The other $6.8 \%$ is explained by other factors outside the model and the error term. The p-value of $0.00<0.01$, thus, null hypothesis is rejected and alternative hypotheses accepted. That is, financial crimes can be combated through the application of forensic accounting techniques of BIT and FRAT in the Nigerian public sector. The regression line of: $\mathrm{ANFO}=0.413+0.022 \mathrm{~b}_{1}+0.346 \mathrm{~b}_{2}+0.522 \mathrm{~b}_{3}+\mathrm{Ut}$ also indicated that given a unit increase in the role of company accounts will lead to the generation of accounting information for decision making of SMEs in Nigeria. So far, all the results from this study indicated that the income statement, statement of financial position and cash flow statement play significant roles in generating accounting information for measuring performance, determining financial position and decision making of SMEs in Nigeria. But the result found that many operators of SMEs in Osun State hired unskilled accounting personnel which make their accounting information unsuitable for decision making and create difficulties to measure their business performances and liquidity position

\section{Conclusion and Recommendations}

Company accounting are very essential for decision making from the view point of majority of the respondents, they appreciate the need for preparing yearly company accounts and reports for their businesses. All the results above agreed with the theoretical expectation of this study since it is expected that if the operators of SMEs especially the limited liability companies prepare and maintain accurate and adequate company accounts, it will facilitate the means of generating reliable and sufficient accounting information that will aid their decision making in Nigeria. Findings showed that there is strong positive relationship between keeping of company accounts and accounting information generation for decision making of SMEs in Nigeria. It is therefore recommended that business organization operators should embrace and maintain proper company accounting practices by hiring knowledgeable and experienced accounting workers to enable them receiving financial information for effective decision making.

\section{Acknowledgment}

We the aforementioned wish to thank and appreciate the effort of Dr. F. O. Olaoye and Prof. G. T. Akinleye of Accounting Department, Ekiti State University, Ado-Ekiti, Nigeria. However, this work is a self sponsored research.

\section{Declaration}

We, the aforementioned declare that the article sent for publication in your journal has not been published or submitted for printing at any other publisher. The content of the article does not infringe the copyright, legal or material interest of other persons.

We declare that we are familiar with the principle of plagiarism which in this case does not apply.

We declare that we have written the article independently. 


\section{Disclosure statement}

No potential conflict of interest was reported by the authors. We also give my consent for publishing the article on the Publisher's website and any other institutional repository.

1. Mr. Azeez Ayoola. OLAOYE

2. Dr. C. O. Olaoye

\section{REFERENCES}

Abdul-Rahamon, O. A., \& Adejare, A. T. (2014). The Analysis of the impact of Accounting Records Keeping on the Performance of the Small Scale Enterprises. International Journal of Academic Research in Business and Social Sciences, 4(1), ISSN: 2222-6990.

Abor, J. \& N. Biekpe, N. (2006). Small Business Financing Initiatives in Ghana, Problems and Perspectives in Management, 4(3), 69-77.

Ademola, G. O., Samuel O. J.\& Ifedolapo O. (2012), The Roles of Record Keeping In the Survival and Growth of Small Scale Enterprises in Ijumu Local Government Area of Kogi State. Global Journal of Management and Business Research Volume 12 Issue 13 Version

Akande, O. O (2011). Accounting Skill as a Performance Factor for Small Businesses in Nigeria, Journal of Emerging Trends in Economics and Management Sciences (JETEMS) 2 (5): 372-378

Anuolam, O. M, Onyema, T. E. \& Ekeke, U. (2016). Forensic accounting and financial crimes: Adopting the inference, relevance and logic solution approach. West African Journal of Industry and Academic Research, 17, Pp.126-132.

Baldwin, J. R., Bian L., Dupuy, R \& Gellatly, G (2000). Failure rates for new Canadian firms: new perspectives on entry and Becker, B. E \& Huselid, M. A (2005). Strategic human resource management: where do we go from here? Journal of Management, 32: $898-892$.

Bouri, A., Breij, M., Diop, M., Kempner R., Klinger B \& Stevenson, K (2011). Report on support to SMEs in developing countries through financial intermediaries.

Halabi, C. E \& Lussier, R. N (2014). A model for predicting small firm performance, Journal of Small Business and Enterprise Development, 21 (1): $4-25$.

Ismaila B (2011). Financial performance measurement of manufacturing small to medium enterprises in Pretoria: a multiple exploratory study, Unpublished MBA Dissertation, University of South Africa.

Jefferson, K (2012). Tips for Better Managing your Bookkeeping Records.

McLarty, R., Pichanic, M \& Sarapova, J (2012). Factors influencing the performance of SMEs: An empirical study in the Czech Republic, International Journal of Management, 29 (3): 36 - 47.

Mutambanengwe, J. (2012). Obstacles to SME Success in the Country, The Financial Gazette.

Olaoye A.A (2012). Advanced Financial Accounting, Nigeria, Adex Publishing Limited.

Osunwole, O.O (2013). Appraisal of the role of international financial reporting standards (IFRS) in ensuring full disclosure of relevant information by business organizations in Nigeria. A paper presented at the $2^{\text {nd }}$ annual national conference of Falculty of Financial Studies, Osun State Polytechnic, Iree, between $23^{\text {rd }}-27^{\text {th }}$ September, 2013, pg 1-17.

Okafor, R. G. (2012). Financial management practices of small firms in Nigeria: Emerging tasks for the accountant. European Journal of Business \& Management, 4(19), 159-169.

Okoh, L. O. \& Uzoka, P. (2012). The Role of Accounting Information in the Survival of Small Scale Businesses in Warri, Delta State, Nigeria. International Journal of Economic Development Research and Investment,3. 40-44.

Onaolapo A. A., \& Adegbite, T. A. (2014). The analysis of the impact of accounting records keeping on the performance of the small scale enterprises. International Journal of Academic Research in Business and Social Sciences, 4, 1-17.

Onaolapo, A.A, Fasina, H.T, Opoola, N.A and Olatunji, A. (2011) Basic Accounting One Ogbomosho.

Oladejo M. (2008). Essentials of management and accounting (2nd Ed.): Johnny Printing Works Ikeja, Peace Concept, 32-93.

Rathnasiri U.A.H.A. (2014). Financial reporting practices of small and medium enterprises (SMES) In Sri Lanka. South East Asia Journal of Contemporary Business, Economics and Law, 4, 15- 23.

Sauser, W. I (2005). Starting Your Own Business? Prepare for Success, SAM Management in Practice, 3 (1): 1 - 4.

Simpson, M., Padmore, J \& Newman, N (2012). Towards a new model of success and performance in SMEs, International Journal of Entrepreneurial Behaviour and Research, 18 (3): 264 - 285.

Smallbone, D., Welter, F., Voytovich, A \& Egorov, I (2010). Government and entrepreneurship in transition economies: the case of small firms in business services in Ukraine, Service Industries Journal, 30 (5): 655 670.

Williams. A. J. (2010). A longitudinal analysis of the characteristics and performance of small business in Australia, Institute of Industrial Economics, 2(3) 201-258. 